\title{
Androlaelaps rotundus FONSECA (ACARI: LAELAPIDAE) ASSOCIATED WITH AKODONTINE RODENTS IN PARAGUAY: A MORPHOMETRIC EXAMINATION OF A PLEIOXENOUS ECTOPARASITE
}

\author{
GETTINGER, D. ${ }^{1}$ and OWEN, R. D. ${ }^{2}$ \\ ${ }^{1}$ Department of Biology, University of Central Arkansas, Conway, AR 72035 \\ ${ }^{2}$ Department of Biological Sciences, Texas Tech University, Lubbock, TX 79409-3131 \\ Correspondence to: Donald Gettinger, Department of Biology, University of Central Arkansas, Conway, \\ AR 72035, e-mail: DONALDG@mail.uca.edu \\ Received May 15, 1998 - Accepted November 20, 1998 - Distributed August 31, 2000
}

(With 4 figures)

\begin{abstract}
A multivariate analysis of morphometric data suggests that the nominally pleioxenous ectoparasite, Androlaelaps rotundus, includes at least three distinct host-associated populations in Paraguay. Where multiple akodontine hosts occur sympatrically, each host species is accompanied by a morphologically distinct mite population. These host-mite associations were consistent across all localities, implying that $A$. rotundus is a complex of unrecognized species.
\end{abstract}

Key words: ectoparasites, laelapidae, Androlaelaps, Eubrachylaelaps, akodontini, Akodon, Bolomys, Paraguay.

\section{RESUMO}

\section{Androlaelaps rotundus Fonseca (Acari: Laelapidae) associada com roedores akodontinos no Paraguay: um exame morfométrico do ectoparasito pleoxeno}

Uma análise multivariada de dados morfométricos sugere que o ectoparasito pleixeno Androlaelaps rotundus, composto por distintas populações hospedeiro-associadas, no Paraguai. Quando múltiplos hospedeiros akodontinos ocorrem simpatricamente, cada espécie de mamífero é acompanhada por uma população morfologicamente distinta de ácaro. Estas associações hospedeiro-ácaro repetiram-se nos estudos realizados em diferentes localidades, mostrando que $A$. rotundus é um complexo de espécies críticas indistinguíveis.

Palavras-chave: ectoparasitos, laelapidae, Androlaelaps, Eubrachylaelaps, akodontini, Akodon, Bolomys, Paraguai.

\section{INTRODUCTION}

The laelapid mite subgenus Eubrachylaelaps Ewing occurs throughout the New World, associated with peromyscine rodents in North America and with akodontine rodents in Sout America. The subgenus is morphologically diverse in Nort America, with seven species recognized presently. In Sout America only one nominal species, Androlaelaps (Eubrachylaelaps) rotundus Fonseca, is known. This widely distributed mite has been reported in all ectoparasite surveys where akodontine rodents are present (Botelho \& Williams, 1980; Castro et al., 1987; Fonseca, 1958; Furman, 1972; Lareschi, 1996; Linardi et al., 1987; Linardi et al., 1991; Mares et al., 1989; Mauri, 1964; Mauri \& Capri, 1970; Whitaker \& Dietz, 1987; Whitaker \& Abrell, 1987), and displays a pleioxenous association with a number of different, but phylogenetically related, akodontine hosts.

In Paraguay, akodontine rodents compose a prominent component of the small mammal fauna. 
Many localities have more than one akodontine species, and populations of $A$. rotundus may occur on different host species at the same locality. We used a comparative approach to examine the hypothesis that populations of $A$. rotundus infesting different host species in the same region are morphologically distinct. The study has three objectives: (1) evaluate the utility of a simple set of characters in describing morphological variation in A. rotundus, (2) examine the mite populations infesting different akodontine hosts within and among localities, and (3) evaluate the monotypy of $A$. rotundus.

\section{TAXONOMIC HISTORY AND HOST ASSOCIATIONS}

Androlaelaps (Eubrachylaelaps) rotundus is associated strongly with South American rodents of the tribe Akodontini. Although many studies have emphasized the broad host range of these mites, including numerous records from non-akodontines, prevalences and intensities of infestation support the primacy of a biological relationship with akodontine rodents. Problems inherent in the design of surveys, sampling biases, and the instability of both mammal and arthropod systematics, often make it difficult to gain a clear understanding of naturally occurring associations. For example, in Venezuela, Furman (1972) reported A. rotundus from seven species of sigmodontine rodents, two murine rodents, a caviomorph rodent, a marsupial, several species of bats, and a bird. However, of a total of 772 mites, 719 (93\%) were recorded from 70 individuals of the akodontine, Akodon urichi J. A. Allen \& Chapman, 1897. The importance of the association between Androlaelaps rotundus and Akodonurichi is revealed clearly by a prevalence of 60 percent, and mean intensity of 10.27 mites per infested host individual.

Androlaelaps rotundus was first described from an "unidentified wild mouse" in the State of São Paulo, Brazil (Fonseca, 1935). Although the type host was not known, a series of topotypes (specimens from the same locality) of A. rotundus were collected from the akodontine Bolomys lasiurus (Lund, 1841) (Furman, 1955; Jameson, 1951). Later, when Fonseca (1958) examined a collection of mites from small mammals surveyed by the National Plague Service in northeastern Brazil, he reported A. rotundus from a long list of host species, but most of the mites were taken from two akodontines, identified as Zygodontomys pixuna and Akodon arviculoides. Fonseca (1957) concluded that $A$. rotundus is a highly variable mite species, capable of infesting multiple host species. However, because Z. pixuna and A. arviculoides are now synonyms of Bolomys lasiurus (Wilson \& Reeder, 1993), Fonseca`s taxonomic decision to refer these specimens to a single species appears to have been justified biologically. Nevertheless, this conclusion may have influenced other taxonomists when they encountered mites on other akodontines.

The diversity of the primary host group, the Akodontini, increases in both temperate and Andean habitats, and A. rotundus has been reported from a large number of different akodontine hosts in the southern cone countries of Chile, Bolivia, Argentina, Uruguay, and Paraguay. In a small collection of ectoparasites from Paraguay, Whitaker and Abrell (1987) reported A. rotundus from Akodon nigrita (Lichtenstein, 1929) and Akodon varius Thomas, 1902. In Argentina, Mauri \& Capri (1970) noted the specificity of association between A. rotundus and hosts of the genus Akodon, including Akodon azarae (J. Fischer, 1829), A. kempi (Thomas, 1917), A. obscurus Waterhouse, 1837 (= Bolomys obscurus), A. varius, and Akodon boliviensis tucumanensis (= A. spegazzinii Thomas). Lareschi (1996) reported a strong association betweem $A$. rotundus and Akodon azarae in the province of Buenos Aires, Argentina. In Brazil, A. rotundus was reported from Akodon cursor (Winge, 1887), from the Federal District (Mares et al., 1989) and the State of Santa Catarina (Linardi et al., 1991). In addition, Bolomys lasiurus is a common akodontine in many parts of central Brazil, and A. rotundus has been reported from this host in the Brazilian State of Minas Gerais (Botelho \& Williams, 1980; Linardi et al., 1987; Whitaker \& Dietz, 1987), and the Federal District, near Brasília (Mares et al., 1989).

\section{MATERIAL AND METHODS}

In an ongoing survey of small mammals in Paraguay, rodents and small marsupials are captured in live traps, and etherized and brushed for ectoparasites before they are prepared as standard museum specimens. Ectoparasite sampling techniques are described in Gettinger (1992). All 
mite specimens used in this study were mounted individually in Hoyer's medium, ringed in glyptal, and measured with a stage-calibrated ocular micrometer.

The adult female mite was used in all morphometric analyses, because it is the most abundant life stage in populations sampled from the host mammal, and it is the stage upon which formal mite species descriptions are based. Thirtyeight continuous characters were chosen, representing different parts of the laelapid body: dorsal shield (two), dorsal chaetotaxy (eight), gnathosoma (four), sternal shield (six), epigynial shield area (five), anal shield (five), peritreme (one), and legs (seven). See Appendix 1 for a list and descriptions of characters. Some characters were chosen because they have been used in the taxonomic literature as discriminators between taxa, and others were added as descriptors of shape. Mite specimens were selected randomly for measurement, but were included only if all 38 characters could be seen clearly and measured. General morphological terminology follows Krantz (1978).

The NT-SYS multivariate statistical package (Rohlf, 1993) was used to perform all numerical systematic analyses and to display results. Each of the 38 characters was standardized to a mean of 0.0 and a standard error of 1.0, to equalize the effect of character size on the relationships among individuals. The first three eigenvectors were extracted from the pair-wise character correlation matrix. The original matrix of standardized measurements was then projected onto these three eigenvectors, and a three dimensional model was constructed based on these projections. This model enables visualization of inter-individual relationships in the three-dimensional space that best represents the complete (38-dimensional) character space. In addition, a minimum spanning tree among the 82 individuals was calculated from inter-individual distances based on the standardized characters, and this tree was mapped onto the three-dimensional model. This enhances visualization of relative inter-individual distances and enables detection of distortions in the relationships as depicted in the 3-D model.

Because the initial principal component analysis indicated the presence of well-delineated subsets of individuals within the data, additional analyses were conducted on these subsets separately, to detect patterns of host-related or geographic variation within these groups of mites. These analyses followed the same protocol described previously.

The 82 specimens of Androlaelaps rotundus that were used in this study were collected from four species of akodontine at 17 localities in nine Paraguayan departments (Fig. 1). In the following listing of host specimens, the number preceeded by "TK" is the field catalog number. One female mite was selected randomly from each host individual. Host voucher specimens will be deposited in the Museo Nacional de Historia Natural del Paraguay, and the Museum of Texas Tech University.

Locality numbers, names and descriptions are those that are being used uniformly in publications pertaining to the "Mammals of Paraguay and their Ectoparasites" project (Fig. 1). Each TK number is a unique field catalog number that is associated with a single primary specimen and with all materials collected from that specimen. (1) Estancia La Victoria $\left(23^{\circ} 39.03^{\prime} \mathrm{S}, 58^{\circ} 34.79^{\prime} \mathrm{W}\right)$, Depto. Presidente Hayes: TK60032, TK60033, TK60055, Akodon azarae; TK60072, A. toba, TK60108, TK60109, TK60110, TK60128, TK60175, TK60176, TK60198, TK60202, Bolomys lasiurus. (2) Estancia El $43\left(21^{\circ} 56.20^{\prime} \mathrm{S}, 60^{\circ} 14.56^{\prime} \mathrm{W}\right)$ and Cañada Elisa (22 02.11'S, 60 $19.92^{\prime}$ W), Depto. Boquerón: TK60207, TK60212, TK60213, TK60222, A. toba; TK60278, B. lasiurus. (3) Cerro León (20 26.25'S, $\left.60^{\circ} 19.19^{\prime} \mathrm{W}\right)$, Depto. Alto Paraguay: TK60437, $B$. lasiurus. (5) Lago Ypoá ( $\left.26^{\circ} 01.35^{\prime} \mathrm{S}, 5^{\circ} 28.73^{\prime} \mathrm{W}\right)$, Depto. Paraguarí: TK60581, TK60582, TK60595, A. azarae; TK60579, B. lasiurus. (8) Isla Yacyretá $\left(27^{\circ}\right.$ 24.49'S, 56 45.79'W), Depto. Misiones: TK60828, B. lasiurus. (9) Parque San Rafael $\left(26^{\circ} 45.32\right.$ 'S, $55^{\circ}$ 51.83'W), Depto. Itapúa: TK60892, TK60929, TK60948, A. cursor; TK60894, TK60902, TK60958, B. lasiurus. (12) Cerro Corá $\left(22^{\circ} 37.20^{\prime} \mathrm{S}, 56^{\circ}\right.$ 02.62'W), Depto. Amambay; TK61305, A. cursor. (14) Estancia Yacaré (26 39.49'S, 58 04.07'W), Depto. Ñeembucú: TK61705, TK61706, TK61726, TK61764, A. azarae; TK61729, TK61732, A. cursor. (15) Reserva Natural del Bosque Mbaracayú $\left(24^{\circ}\right.$ 08.75'S, 55 19.14'W), Depto. Canindeyú: TK61791, TK61794, TK61816, A. cursor; TK61813, TK61849, TK61855, TK61924, B. lasiurus. (16) Estancia Loma Porá (23 33.15'S, 57 34 34'W), Depto. Presidente Hayes; TK61936, TK61937, TK62051, TK62074, 
TK62100, A. azarae; TK62087, TK62088, TK62205, TK62207, A. toba; TK61983, TK61984, TK61985, TK62036, TK62125, TK62126, TK62127, TK62129, TK62130, B. lasiurus. (17) Laguna Placenta $\left(21^{\circ}\right.$ 08.62'S, 59 $24.86^{\prime} \mathrm{W}$ ) and Estancia Tres Marias (21 ${ }^{\circ}$ 18.09'S, 59 33.73 'W), Depto. Alto Paraguay: TK62223, A. toba; TK62224, TK62228, TK62431, TK62433, B. lasiurus. (18) Estancia Samaklay (23 28.81'S, 59 48.43 'W), Depto. Presidente Hayes:
TK62654, TK62655, TK62662, TK62712, A. toba; TK62525, TK62578, TK62673, TK62684, TK62685, B. lasiurus. (20) Dest. Gabino Mendoza (20 03.30'S, $61^{\circ}$ 47.22'W), Depto. Alto Paraguay and Parque Cué ( $20^{\circ}$ 07.65' S, 61 $\left.1^{\circ} 45.40^{\prime} \mathrm{W}\right)$, Depto. Boquerón: TK63277, TK63297, TK63300, TK63309, TK63319, A. toba. (21) Reserva Itabó $\left(24^{\circ} 27.68^{\prime} \mathrm{S}, 54^{\circ}\right.$ 38.33'W), Depto. Canindeyú: TK63515, TK63549, B. lasiurus.

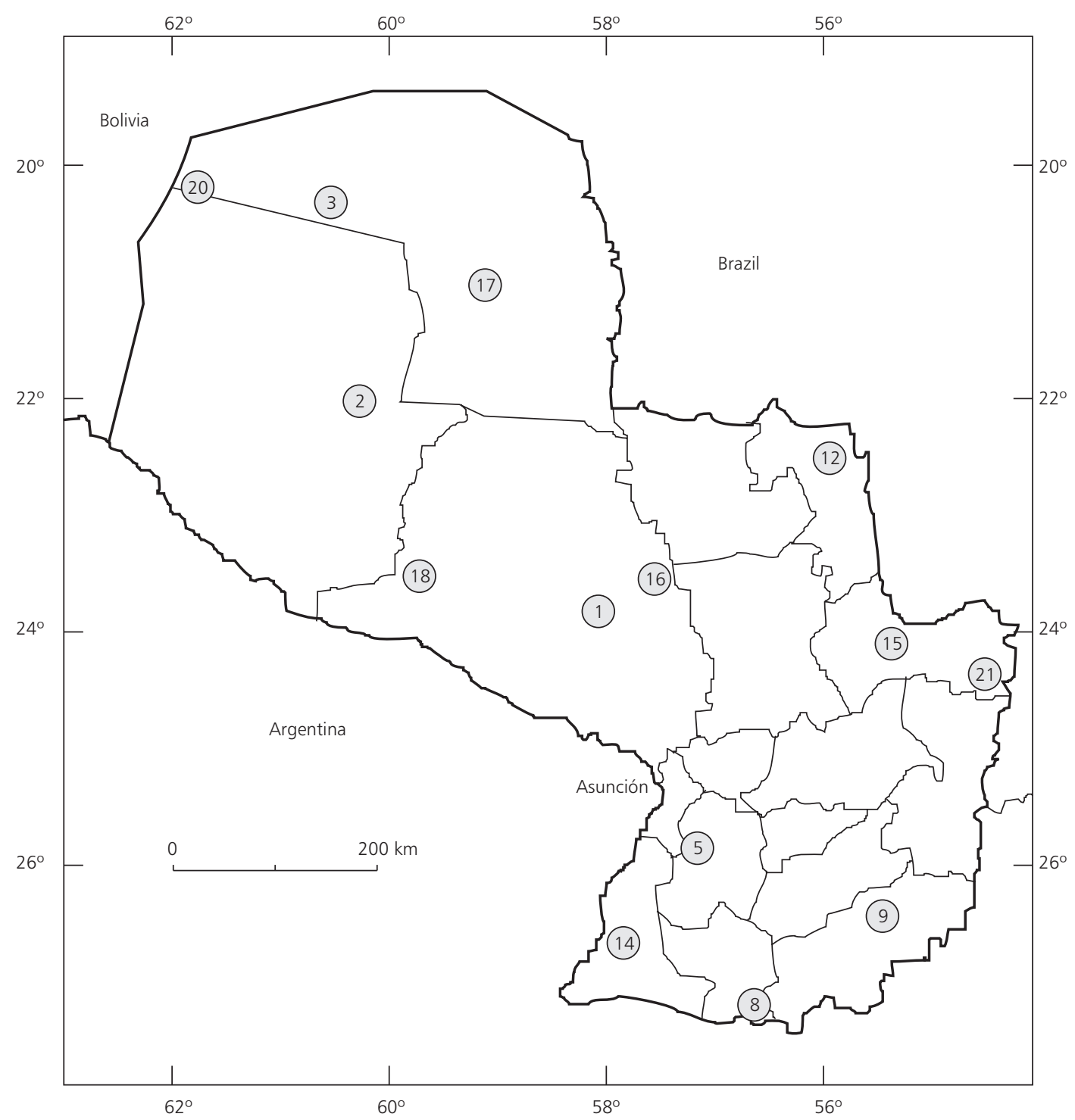

Fig. 1 - Map of Paraguay indicating localities from which mites were examined. See text for locality descriptions and lists of mites and akodontine hosts examined from each locality. 


\section{RESULTS}

A projection of the individual mites onto the first three principal components (Fig. 2), resulted in three distinct morphological groupings: (1) mites collected from Akodon cursor ("c" in the Fig. 2); (2) mites collected from Bolomys lasiurus ("B"); and (3) mites collected from Akodon azarae ("a") and from A. toba (" $\mathrm{t}$ "). The first three components account for $66.4,13.0$, and 3.6 percent of the observed variance, respectively (Table 1 ). An evaluation of the minimum-spanning tree indicates that there is no noteworthy distortion of the relationships among mite individuals (i.e., specimens which are placed close together in the model also are closely connected by the tree).
33 of 38 standardized characters load highly on $\mathrm{PC} 1$ (all positively), indicating that this component is primarily an expression of size (Table 1). The mites from Akodon cursor are smallest, those from $A$. azarae and $A$. toba the largest, and those from Bolomys lasiurus are of intermediate size (Fig. 2). Four characters load heavily on PC2; S3S3, S5S5, and GWGS correlate positively, and LPARA negatively. This component serves to discriminate between mites from B. lasiurus and those from A. cursor, with the mites from $A$. azarae and $A$. toba intermediate on this component. Although mites from A. azarae and mites from $A$. toba are separated by factors pertaining to $\mathrm{PC} 3$, no characters load heavily on this component, and the component is not significant by the broken-stick model (Rohlf, 1993).

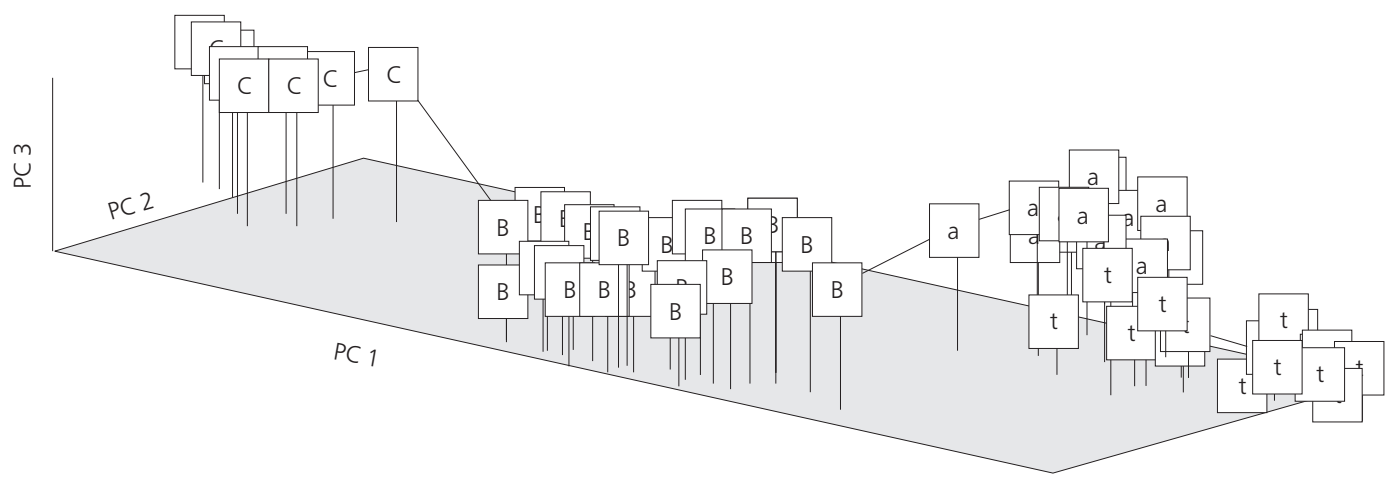

Fig. 2 - Three-dimensional diagram, with minimum-spanning tree, resulting from principal component analysis of all mite specimens. Mites labeled according to host species, as follows: a, A. azarae; c, Akodon cursor; t, A. toba; B, Bolomys lasiurus.

An analysis including only mites from Akodon azarae and A. toba suggests that these two groups of mites are distinct morphologically (Fig. 3). Although some overlap exits between these two groups along PC1, the minimumspanning tree includes only one connection between them, reinforcing the distinctness of the groups. Although the first three principal components are all significant by the two groups, and it is only this component on which characters load heavily. 17 of the 38 characters ( 44.7 percent) load heavily on PC1, all positively, indicating that a subset of about half of the characters examined contributes to a size component that distinguishes the mites associated with these two host species.
To compare host species variation with geographic variation, mites collected from Bolomys lasiurus were assigned to three groups based on collection locality: C, Chaco localities (western region); R, localities along the Paraguay River; and $\mathrm{E}$, localities in the eastern region of Paraguay. Based on these groupings, principal component analysis indicates no discernible pattern of geographic variation among these mite populations (Fig. 4). Although the first three components are significant by the broken-stick model, only five characters load heavily on any component (four on PC1, one on PC2). Evidently, no characters exhibit discernable geographic patterning in mites from this host species. 


\section{TABLE 1}

Loadings of characters on components 1, 2, and 3, and scaled eigenvalues (percentage of matrix variance explained) for those components, from principal component analysis of: (1) all mite specimens, (2) mites from Akodon azarae and A. toba, and (3) mites from Bolomys lasiurus.

Underlining indicates high (i.e., 0.7 or greater) loading of a character on a component. *, indicated that the component is "significant", i.e., explains a larger percentage of the matrix variance than would be expected randomly, by the broken-stick model (Rohlf, 1993). Characters and their acronyms are listed in Appendix 1.

\begin{tabular}{|c|c|c|c|c|c|c|c|c|c|}
\hline \multirow[b]{2}{*}{ Character } & \multicolumn{3}{|c|}{ All Mite Specimens } & \multicolumn{3}{|c|}{ A. azarae and A. toba } & \multicolumn{3}{|c|}{ Bolomys lasiurus } \\
\hline & PC1 & PC2 & PC3 & PC1 & PC2 & PC3 & PC1 & PC2 & PC3 \\
\hline LDS & $\underline{0.957}$ & 0.229 & 0.037 & $\underline{0.891}$ & 0.166 & 0.072 & $\underline{0.783}$ & 0.020 & 0.127 \\
\hline WDS & $\underline{0.921}$ & 0.326 & -0.012 & $\underline{0.817}$ & 0.168 & 0.138 & $\underline{0.801}$ & 0.085 & 0.138 \\
\hline AJ5AJ5 & $\underline{0.884}$ & 0.131 & -0.032 & 0.585 & 0.276 & -0.208 & 0.459 & -0.339 & 0.039 \\
\hline AZ5AZ5 & $\underline{0.875}$ & -0.291 & -0.063 & $\underline{0.728}$ & 0.188 & 0.050 & 0.542 & -0.050 & 0.280 \\
\hline LAJ5 & $\underline{0.738}$ & -0.045 & 0.566 & -0.588 & -0.360 & -0.120 & 0.082 & 0.287 & 0.244 \\
\hline LAZ5 & $\underline{0.722}$ & -0.084 & 0.580 & -0.600 & 0.507 & -0.106 & -0.016 & 0.195 & 0.373 \\
\hline BJ5BJ5 & $\underline{0.836}$ & 0.367 & -0.196 & $\underline{0.747}$ & 0.066 & -0.086 & 0.380 & -0.176 & 0.399 \\
\hline BZ5BZ5 & $\underline{0.867}$ & 0.317 & -0.040 & 0.582 & 0.134 & -0.177 & 0.386 & -0.265 & 0.455 \\
\hline LBJ5 & $\underline{0.696}$ & -0.201 & 0.402 & -0.260 & 0.139 & 0.679 & 0.167 & 0.422 & -0.365 \\
\hline LBZ5 & $\underline{0.870}$ & 0.267 & 0.009 & 0.587 & 0.242 & 0.204 & 0.106 & $\underline{0.752}$ & 0.011 \\
\hline CAPCAP & $\underline{0.908}$ & 0.234 & -0.085 & $\underline{0.784}$ & 0.063 & -0.066 & 0.016 & -0.324 & 0.649 \\
\hline LCAP & 0.870 & $-\underline{0.165}$ & 0.013 & 0.539 & 0.106 & 0.082 & 0.431 & 0.088 & -0.388 \\
\hline LINN & $\underline{0.717}$ & -0.644 & 0.107 & 0.349 & 0.109 & -0.183 & 0.357 & 0.252 & -0.049 \\
\hline CAPINN & $\underline{0.960}$ & 0.107 & -0.009 & $\underline{0.771}$ & -0.017 & -0.137 & 0.414 & -0.286 & 0.343 \\
\hline LSS & $\underline{0.846}$ & -0.032 & -0.207 & $\underline{0.736}$ & 0.151 & -0.265 & 0.212 & -0.545 & 0.493 \\
\hline WSS & 0.844 & 0.271 & 0.059 & 0.441 & 0.551 & 0.408 & 0.667 & -0.037 & -0.067 \\
\hline S1S1 & 0.915 & 0.053 & 0.076 & 0.369 & 0.568 & 0.177 & 0.552 & 0.164 & 0.005 \\
\hline S3S3 & 0.442 & $\underline{0.774}$ & 0.049 & 0.218 & 0.632 & 0.178 & $\underline{0.779}$ & -0.167 & -0.129 \\
\hline LS1 & $\underline{0.745}$ & -0.561 & -0.151 & $\underline{0.732}$ & -0.515 & 0.009 & -0.245 & 0.492 & -0.044 \\
\hline LS3 & $\underline{0.861}$ & -0.283 & -0.089 & $\underline{0.707}$ & -0.369 & 0.181 & 0.258 & 0.649 & 0.301 \\
\hline LGS & $\underline{0.810}$ & -0.040 & 0.123 & 0.239 & 0.641 & -0.362 & 0.629 & -0.168 & -0.076 \\
\hline S5S5 & 0.303 & $\underline{0.875}$ & -0.011 & 0.426 & 0.433 & 0.566 & $\underline{0.784}$ & -0.174 & -0.387 \\
\hline GWGS & 0.127 & $\underline{0.764}$ & -0.047 & 0.337 & 0.454 & 0.461 & 0.675 & -0.106 & -0.233 \\
\hline LS4 & 0.813 & -0.162 & -0.375 & $\underline{0.885}$ & -0.239 & 0.034 & -0.189 & 0.540 & 0.506 \\
\hline LS5 & $\underline{0.886}$ & -0.346 & -0.216 & $\underline{0.920}$ & -0.190 & -0.009 & 0.050 & 0.379 & 0.587 \\
\hline LPER & $\underline{0.963}$ & -0.034 & -0.020 & $\underline{0.706}$ & 0.249 & -0.131 & 0.295 & -0.427 & 0.004 \\
\hline LPARA & 0.587 & -0.724 & -0.101 & $\underline{0.732}$ & -0.185 & -0.346 & 0.335 & 0.265 & 0.165 \\
\hline LPOST & $\underline{0.809}$ & -0.214 & -0.269 & $\underline{0.782}$ & -0.128 & -0.069 & 0.268 & 0.057 & 0.119 \\
\hline EDGE & $\underline{0.757}$ & 0.578 & -0.055 & $\underline{0.785}$ & -0.235 & -0.054 & 0.502 & 0.010 & 0.044 \\
\hline PARPAR & $\underline{0.724}$ & -0.155 & -0.074 & 0.386 & 0.182 & 0.115 & 0.606 & -0.076 & -0.129 \\
\hline GWAS & 0.570 & -0.239 & -0.027 & 0.336 & 0.336 & -0.207 & 0.642 & -0.295 & 0.040 \\
\hline PROX1 & $\underline{0.935}$ & -0.018 & -0.160 & $\underline{0.846}$ & -0.253 & -0.012 & 0.670 & 0.400 & 0.047 \\
\hline DIST1 & $\underline{0.943}$ & 0.091 & 0.070 & 0.524 & 0.020 & -0.386 & 0.462 & 0.364 & -0.336 \\
\hline POST2 & $\underline{0.960}$ & 0.001 & -0.025 & $\underline{0.717}$ & -0.229 & 0.060 & 0.400 & 0.148 & -0.298 \\
\hline
\end{tabular}


TABLE 1 (continuação)

\begin{tabular}{|l|c|c|c|c|c|c|c|c|c|}
\hline & \multicolumn{4}{|c|}{ All Mite Specimens } & \multicolumn{3}{c|}{ A. azarae and A. toba } & \multicolumn{3}{c|}{ Bolomys lasiurus } \\
\hline Character & PC1 & PC2 & PC3 & PC1 & PC2 & PC3 & PC1 & PC2 & PC3 \\
\hline POST3 & $\underline{0.851}$ & 0.174 & -0.069 & 0.490 & -0.325 & 0.252 & 0.337 & 0.477 & 0.308 \\
\hline POST4 & $\underline{0.850}$ & -0.417 & 0.150 & 0.279 & 0.558 & -0.054 & 0.227 & 0.436 & 0.140 \\
\hline FEM1 & $\underline{0.916}$ & 0.178 & 0.064 & 0.350 & -0.501 & 0.523 & 0.469 & 0.175 & -0.039 \\
\hline GEN1 & $\underline{0.921}$ & -0.083 & 0.161 & -0.065 & -0.313 & 0.467 & 0.142 & 0.268 & -0.258 \\
\hline \% VARIANCE & $66.4^{*}$ & $13.0^{*}$ & 3.6 & $37.5^{*}$ & $11.1 *$ & $6.9^{*}$ & $21.4^{*}$ & $10.7^{*}$ & $8.2^{*}$ \\
\hline
\end{tabular}

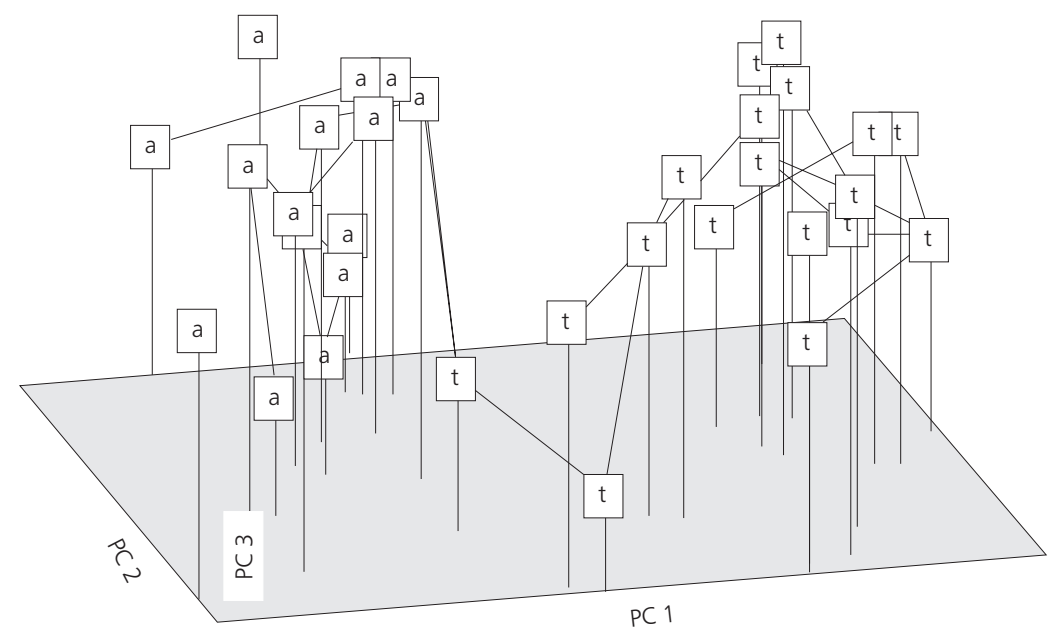

Fig. 3 - Three-dimensional diagram, with minimum-spanning tree, resulting from principal component analysis of mites collected from Akodon azarae and A. toba. Specimen labels as in Fig. 1.

\section{DISCUSSION}

The ectoparasite, Androlaelaps rotundus, comprises at least three, and quite possibly four, morphologically distinct species in Paraguay. The initial principal component analysis of the entire data-set produced three non-overlapping groups of mites. Subsequent ordinations of mite from Akodon azarae and A. toba confirmed the presence of distinctive mite populations on each host species. Observed patterns are consistent with host species variation, and imply that mite groups have differentiated through evolutionary time on their respective hosts.

An ectoparasitic arthropod species that preferentially infests a number of different, but phylogenetically related hosts must have adapta- tions for dispersing both within and among host species. Although the etymology of the name Laelapidae implies swiftness, the locomotor abilities of these mites are inadequate for the task of actively dispersing. If these acarines are dependent on the host for dispersal (phoresy), transmission between hosts would tend to be vertical, between conspecifics, with little opportunity for transfer to other host species. This is especially true for closely related host species, which in vertebrates tend to be ecologically divergent (especially in sympatry).

The mites associated with Akodon azarae and $A$. toba are distinguished easily from those associated with A. cursor and with Bolomys lasiurus. Besides being much larger, with dorsal shield lenght greater than 700 micrometers, they also have a distinctive anal shield (longer than wide). 


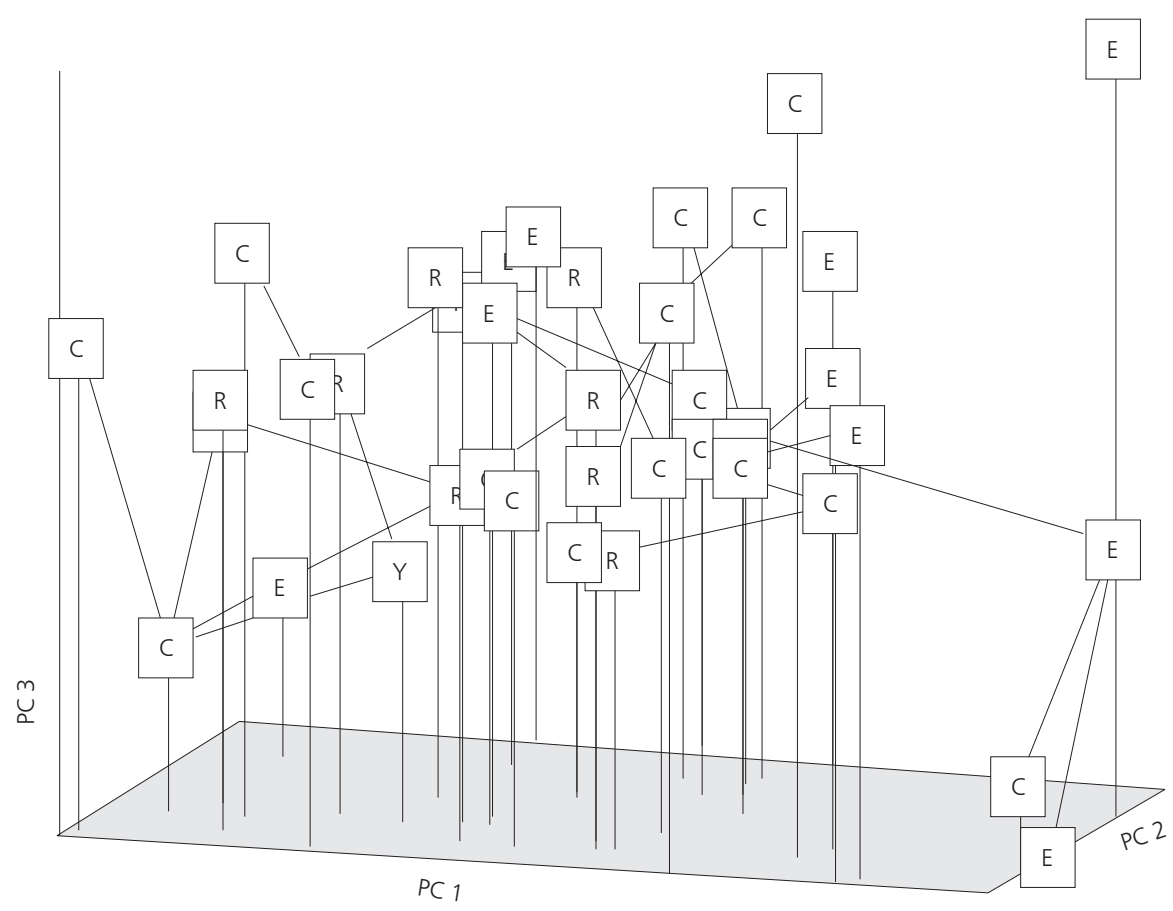

Fig. 4 - Three-dimensional diagram, with minimum-spanning tree, resulting from principal component analysis of mites collected from Bolomys lasiurus. Mites labeled according to geographic origin, as follows: E, eastern region; R, Rio Paraguay; C, Chaco (western region).

These mites are clearly distinctive from the types described by Fonseca (1935), but species boundaries between mites associated with $A$. azarae and $A$. toba are still unclear.

Preliminary analysis has revealed considerable morphological variation between mite populations infesting A. azarae and A. toba. Mites from A. azarae are somewhat smaller, with longer dorsal setae and shorter ventral setae, than mites from A. toba (Table 2). Specimens of A. azarae were collected in central Paraguay on both sides of the Paraguay River, whereas specimens of $A$. toba were collected only west of the Paraguay River, and the two species occurred in sympatry (together with B. lasiurus) at two localities (1 and 16) in the Department of Presidente Hayes.

The mites from A. cursor are much smaller than the original species described by Fonseca (1935). This host was collected only from localities east of the Paraguay River, but was encountered sympatrically with $A$. azarae at locality 14 , and with Bolomys lasiurus at localities 9 and 15. In each case, the mites from each host species are easily distinguishable from those of the other host. Principal component analysis showed clear distinctions among some host-defined groups for Androlaelaps rotundus in Paraguay. Many of the characters are important in describing the morphological variation among samples collected from different host species. At least three, and probably four morphological groups of mites have been distinguished by these 38 characters.

Each group is associated consistently with a specific akodontine host. Furthermore, the mites from Bolomys lasiurus (which has a broad geographic and ecological distribution and occurs in sympatry with all three Akodon species in Paraguay) do not exhibit any pattern of morphological variation associated with geographic factors or sympatry status. To the extent that our samples permit, we observe the same morphological uniformity within host-defined groups, for mites from the three Akodon species. For these reasons, we suspect that in Paraguay Androlaelaps rotundus comprises three or more biological species, at least two of which remain undescribed. 


\section{APPENDIX 1}

Characters and their acronyms used in this study. All characters are direct linear measurements, taken from mounted specimens as described in the text. Dorsal shield length (DSL); dorsal shield width at midlevel (DSW); distance between j5 setae )j5j5); distance between z5 setae (z5-z5); length of j5 (j5L); length of z5 (z5L); distance between J5 setae (J5-J5); distance between Z5 setae (Z5-Z5); length of J5 (J5L); length of Z5 (Z5L); distance between subcapitular setae (CAP-CAP); length of subcapitular setae (CAPL); length of inner hypostomal setae (INNL); distance between subcapitular and inner hypostomal setae (CAP-INN); length of sternal shield (SSL); width of sternal shield at level at second sternal setae (SSW); distance between first sternal setae (S1-S1); distance between third sternal setae (S3-S3); length of anterior sternal setae (S1L); length of posterior sternal setae (S3L); length of epigynial shield (ESL); distance between epigynial setae (E5-E5); greatest width of epigynial shield (ESW); length of poststernal setae (S4L); length of epigynial setae (E5L); length of peritreme (PERI); length of paranal setae (PARAL); length of postanal seta (POSTL); distance from postanal seta to anterior midline of anal shield (POSTEDGE); distance between paranal setae (PARAPARA); greatest width of anal shield (ASW); length of proximal seta, coxa I, (PROXCOX); length of distal seta, coxa I (DISTCOX); length of posterior seta, coxa II (POSTCOX2); length of posterior seta, coxa III (POSTCOX3); length of posterior seta, coxa IV (POSTCOX4); length of anterior dorsal seta, femur I (DFEM1L); length of posterior dorsal seta, genu I (DGEN1L).

Acknowledgments - For valuable logistic support in Paraguay, we are grateful to A. L. Aquino Ortiz (Office of the Scientific Authority, Convention on International Trade in Endangered Species), I. Gamarra de Fox (Museo Nacional de Historia Natural), C. Fox (Dirección de Parques Nacionales y Vida Silvestre), J. O. Usher T. (Universidad Catolica "Nuestra Señora de Asunción"), and C. J. Shuster, as well as other personnel of these offices and of the Fundación Moises Bertoni. We thank C. López-Gonzalez, S. T. Mezik, S. J. Presley, F. Pintos, P. M. Gorresen, R. D. Stevens, I. Mora, H. Amarilla, C. H. Swift, and V. L. Dye for assistance in collecting the hosts and mites examined in this study. C. López-Gonzalez cleaned the akodontine skeletal material to enable identification of host specimens. M. R. Willig provided a thorough and thoughtful review of the manuscript. This work was funded by the National Science Foundation grant DEB-9400926 to R. D. Owen and M. R. Willig; additional support was provided by the Office of the Provost, the Department of Biological Sciences, the Museum of Texas Tech University, and the Ministerio de Agricultura y Ganadería of Paraguay.

\section{REFERENCES}

BOTELHO, J. R. \& WILliaMS, P., 1980, Sobre alguns ectoparasitos de roedores silvestres do Município de Caratinga, Minas Gerais, Brasil. II. Acarofauna. Mem. Inst. Oswaldo Cruz, 75: 47-51.

CASTRO, D. del C., MAURI, R., CICCHINO, A. C. \& MOSQUERA, S., 1987, Ectoparasitos de roedores de la Provincia de Buenos Aires, Argentina (Acarina, Anoplura, Mallophaga y Suctoria). Revsta. Soc. Enr. Arg., 44(3-4): 317-327.

FONSECA, F. da, 1935, Notas de Acareologia, XVIII, Generos e espécies de acarianos parasitos de ratos (Acari, Laelaptidae) (Nota prévia). Mem. Inst. Butantan, 10: 17-23

FONSECA, F. da, 1958, Notas de Acarologia XLIV. Inquérito sobre a fauna acarológica de parasitos no Nordeste do Brasil. Mem. Inst. Butantan, 28: 99-186.

FURMAN, D. P., 1955, Revision of the genus Eubrachylaelaps (Acarina: Laelaptidae) with the descriptions of two new species from Mexico. Ann. Ent. Soc. Amer., 48: 51-59.

FURMAN, D. P., 1972, Laelapid mites (Laelapidae: Laelapinae of Venezuela. Brigham Young Univ. Sci. Bull. Biol. Ser., 27(3): 1-58.

GETTINGER, D., 1992, Host specificity of Laelaps (Acari: Laelapidae) in central Brazil. J. Med. Entomol., 29: 71-77.

JAMESON, E. W., 1951, Eubrachylaelaps martini, a new mite (Acarina: Laelaptinae) from the volcano mouse (Mammalia: Cricetinae). J. Parasitol., 37: 556-559.

KRANTZ, G. W., 1978, A Manual of Acarology, $2^{\text {nd }}$ ed., Oregon State University Book Stores, Corvallis.

LARESCHI, M., 1996, Estudio preliminar de la comunidad de roedores (Rodentia: Muridae) y sus ectoparasitos (Acari, Phthiraptera y Siphonaptera) en Punta Lara (Buenos Aires). Rev. Soc. Entomol. Argent., 55(1-4): 113-120.

LINARDI, P. M., TEIXEIRA, V. P., BOTELHO, J. R. \& RIBEIRO, L. S., 1987, Ectoparasitos de roedores em ambientes silvestres do Município de Juiz de Fora, Minas Gerais. Mem. Inst. Oswaldo Cruz, 82(1): 137139.

LINARDI, P. M., BOTELHO, J. R., XIMENEZ, A. \& PADOVANI, C. R., 1991, Notes on ectoparasites of some small mammals from Santa Catarina state, Brazil. $J$. Med. Entomol., 28(1): 183-185.

MARES, M. A., BRAUN, J. K. \& GETTINGER, D., 1989, Observations of the distribution and ecology of the mammals of the cerrado grasslands of central Brazil. Ann. Carnegie Mus., 58(1): 1-60. 
MAURI, R., 1964, Acaros laelaptidos parasitos de vertebrados. Rev. Soc. Ent. Arg., 32(1-4): 133-141.

ROHLF, F. J., 1993, Numerical taxonomy and multivariate analysis system (NTSYS-pc), version 1.80. Exeter Software, Setauket, New York, pp.

WHITAKER JR., J. O. \& DIETZ, J. M., 1987, Ectoparasites and other associates of some mammals from Minas Gerais, Brazil. Entomol. News, 98: 189-197.
WHITAKER JR., J. O. \& ABRELL, D. B., 1987, Notes on some ectoparasites from mammals of Paraguay. Entomol. News, 98: 198-204.

WILSON, D. E. \& REEDER, D. M. (eds.), 1993, Mammal Species of the World: A Taxonomic and Geographic Reference. Smithsonian Institute, Washington, D.C., $1072 \mathrm{p}$. 